\title{
Corporatist Capitalism: The Politics of Accumulation in South India
}

ELISABETTA BASILE and BARBARA HARRISS-WHITE

\section{THE SOCIAL MATRIX OF ACCUMULATION}

In our tribute we summarise the initial results of field research on one aspect of civil society which was energised in conversations about the politics of markets with Gordon White [White (ed.), 1993]. While the output of Gordon's work on the politics of civil society in China ran rapidly to six papers and a substantial book [White et al., 1996] and then flowed on into fertile intellectual distributaries-civil society and democratisation [Luckham and White, 1996; Robinson and White, 1998]; the politics of social provision [Goodman, White and Kwon, 1998] and the political conditions for effective developmental states [Luckham and White, 1996]-our work on the social regulation of the Indian economy required ethnographic field research, proceeded comparatively at a snail's pace and, in the decade since the original conversations, has generated but three papers and one book [Basile and Harriss-White, 2000; McCartney and Harriss-White, 2000; Harriss-White, 2002a: 2000b]. Three strands of Gordon's work have been indispensible to the framework we use here to examine the impact of the politics of urban organisations on accumulation in South India: civil society, the politics of market organisation and corporatism. In this introduction, first, we will outline the framework of 'social structures of accumulation' (henceforth SSA) and then weave in these strands.

The authors are very grateful for swift and constructive comments on the first draft from Neil Armstrong, Chris Fuller, P.J.Krishnamurthy. They also wish to thank M.V.Srinivasan and hundreds of citizens of Arni for their co-operation over the period 1993-97; and Kaveri and Elinor Harriss for tackling some of their parents' fieldnotes from 1983 and 1973 and Maxine Molyneux and the editors for their comments at and after the Gordon White Memorial Conference, IDS, April 1999. They take sole responsibility for any errors which remain. 
The school of SSA challenges the conventional double reductionism of capitalism to markets and of markets to the economic domain. While orthodox economics externalises the regulative environment, SSA gives it pride of place. It seeks to examine the growth and change in capitalist systems through the complex of social institutions that enable the collection of factors of production, the transformation of money into the means of production, the organisation of production and the reconversion of the product into money [Kotz, McDonough and Reich, 1994]. Institutions and their interrelationships evolve as a period of accumulation comes into being and is sustained, but the consolidation of this institutional matrix has the capacity eventually to undermine the very system it has created. The motors of accumulation may include: institutions structuring labour and management and those managing demand and consumption; the character of industrial organisation; the institutions of finance; the role of the state and of political parties; social institutions of race and gender and the dominant culture or ideology. At the core of this ambitious intellectual agenda is a question about how this continually changing set of structures ensures or undermines stability, by reducing class conflict, conflict within capital and conflict between concentrations of capital.

We use this framework here to help answer the question: within the set of institutions underpinning capitalist accumulation, what is the role played by organisations of civil society? In his political analysis of markets, White [1993:7] grants civic organisations a prominent and contradictory role as shapers of the politics of market organisation. Competition has to be subordinated to collective action for purposes of endogenous regulation. Yet these conditions 'protect the market position' of participants, through unearned rents, to the detriment of those excluded. The balance between positive (regulatory) and negative (exclusionary) effects of such organisations, White concluded, 'needs more thought and investigation' [ibid.]. That is our purpose here. Beforehand, however, we need briefly to introduce and define other key analytical building blocks: civil society, caste and corporatism.

\section{Civil Society, Caste and Corporatism}

White et al. define civil society as 'a sphere of free social interaction and organisation which is separate and independent of the State' [1996:1]. But the term is heavily contested, depending on the terms of the juxtaposition of state to civil society [Keane, 1988]. To add relevance to our study of civic organisations and a new structure to the SSA, we draw some insights from Gramsci [1975]. Civil society consists of the political, cultural and ideological hegemony which a social group exercises over society and by means of which the economy is regulated. The Gramscian concept of civil society combines two spheres of social life: economic interests and 
ideology. The institutions which result (including those crucial for accumulation) are the outcome not only of social contradictions and conflicts but also of the ideological factors by means of which social consent is gained and interests are imposed. Ideology is then recognised as being a major component of the institution-building process.

Two aspects of Indian development-rapid social and economic change and an increasing social complexity-reinforce the relevance of a Gramscian approach. Caste, in both its ideological and its politically organised forms, is central to both aspects.

Caste is 'a specifically Indian form of civil society', characterised by both 'continuity and change' [Fuller: 1996]. Legitimated directly from, 'inextricably intertwined with', Hindu religion and yet transcending Hinduism, caste persists in the foundations of Indian society. The constraint of caste on Indian economic performance has long been debated. That economic liberalisation, and modernity more generally, will dissolve the caste system is now a common insight [Mendelsohn, 1993; Panini, 1996; Jayaram, 1996], seeding hypotheses about determinants and consequences. While castes contribute to the architecture of Indian civil society, each individual caste is a 'dynamic force in interest articulation' [Jayaram, 1996]. While 'modernisation' has undermined or transformed the organisation of caste, it has also revealed its 'tremendous flexibility' [Jayaram, 1996]. Caste groups have shifted ritual position, due to the increasing contact of lower castes with the 'great Hindu tradition' [Karanth, 1996]. The process whereby 'a low caste takes over the customs, ritual, belief, ideology and style of life of a high caste' with the objective of improving 'the economic and political position of the group' is known as 'Sanskritisation' [Srinivas, 1989:56]. Sankritisation in turn accompanies 'modernisation' by which is meant-very specifically—an increasing dissociation of castes from their hereditary occupations. The combined effect of 'modernisation' and of the contested implementation of positive discrimination via the Reservations policy of the Indian Government has been the emergence of a 'dual culture' [Karanth, 1996; Radhakrishnan, 1996]. Castes attempt to claim a low or backward status in relation to the state, while claiming and protecting a high status in relation to society.

The secularisation of caste in India is widely thought to have involved a separation between the Hindu religious sphere and the social-economic sphere. As Béteille suggests [1996:158], the caste system has been 'truncated': its future 'not with religion but with politics'. If 'modernisation' has reworked caste, the question then is what kind of political society is currently being shaped by this transformed institution. The recent literature shows how caste still plays a major continuity role as the economy diversifies. Many occupations, particularly dirty ones, remain casteclustered. This clustering, however, can be (and has been) explained by the distribution of skills and resources, by the imperfections of the labour 
markets affecting the control of individuals over information on economic opportunities, rather than with reference to the caste hierarchy per se [Panini, 1996]. Instead of dissolving caste, liberalisation has revealed a deeply segmented social structure in which caste is connected with networks of other civil organisations that comprehensively regulate economic and social life [Uphadya, 1997; Reiniche, 1996]. The point to note is that distinctions of status, even if they might still be expressed in the idiom of caste, are rooted neither in a caste system nor a caste hierarchy, whose legitimacy has been eroded, but rather in social groups whose differences are legitimated in economic terms [Fuller, 1996].

We can now turn to our hypothesis: that the form of social regulation emerging from the secularisation of caste is corporatist. Corporatism is a form of regulation of the relations between labour, capital and the state, which is based on a specific economic order entirely compatible with authoritarianism [O'Sullivan, 1988]. The play between interest groups defines the associative order that governs social interaction and shapes the SSA. The role of the state may vary, and a common distinction is made in literature between state and societal corporatism (reviewed in White [1996]). In the first form, the state plays a 'directive' role and dominates the relationship both with the corporatist associations and between them. In the second form, theorised by Schmitter [1974] and Cawson [1985], corporatist associations are relatively independent from the state. Here the state performs the role of 'interest intermediation'. Corporatist political exchange combines three sets of interests: the state, capital and labour. The state is no neutral arbiter; instead it is the active synthesiser of corporatist ideals and values, the repositary of a vision of society in which the power of capital and labour is unsymmetrically distributed and biased towards capital. In a corporatist economy, civil society, political society and economy overlap [Mancini, Perrillo and Zagari, 1982].

The neo-corporatist argument is highly relevant to our project on contemporary India. Organisations of economic interests may be created and/or controlled by the state for its own project of accumulation. Such institutions may not contribute to the democratisation of society. Quite the reverse. An alternative conception of the role of institutions of collective economic interest (business and trade associations) is opened up-from that of narrow advancement to that of the mediation of potentially conflicting interest. And in the concrete circumstances of South India attention is alerted to the relationship between caste as a means of organising occupation and its evolving relation to the state.

\section{THE TOWN}

Our empirical material is of two types: a series of three field enquiries into the organisation of local urban capital, labour, commodities and their 
politics, by means of business histories obtained from random six per cent samples of commercial enterprises in 1973-74, 1982-84 and 1993-94 [Harriss, 1991]; and a systematic set of histories, gathered in 1997, of almost all the groups and associations with which the business economy of a small town is linked and in which it is embedded: market organisations, political institutions and civil society associations.

The market town is Arni, located in northern Tamil Nadu and acting as a central place for more than a hundred villages. It is $150 \mathrm{~km}$ south-west of Chennai with an economic base of administration, commerce (increasingly wholesale), paddy trading and milling, silk saree weaving and the workshop manufacturing of gold ornaments. Five per cent of its population is agricultural. According to the censuses, its population has grown from some 39,000 in 1971 to over 60,000 in 2001. The municipality, created in 1951 and upgraded in status 1971, has already engulfed 11 revenue villages. In fact the population directly associated with Arni's urban economy is likely to approach 100,000 , the census population being inflated by transients and by regular commuters from its ring of satellite villages. These resist incorporation into the municipality because of the increases this would make in local taxation-a fact which makes local urban government chronically relatively underfunded.

During the last 20 years the number of businesses visible to our census record of businesses in Arni has trebled. In late 1993 the transformation in its economic base over the previous decade had been nothing short of astonishing. A number of agricultural and 'traditional' artisan activities have declined significantly or disappeared altogether. Agricultural inputs firms have stagnated (as had agricultural production). The activities comprising the economic base ten and twenty years ago have consolidated their position: rice mills have doubled in number as have food wholesaling firms and durable consumer goods retail units, goldsmiths and pawnbrokers. Urban silk manufacturing units have increased by 50 per cent and have spilled over massively into the countryside. Deregulation has led to a threefold increase in fuel depots and increased urban and rural incomes have generated demand for a 30 -fold increase in businesses dealing in non-food agricultural products.

New businesses attest not only to the metropolitanisation of economy and culture but to its rapid globalisation. Brand new telecommunications technologies have appeared: satellite and cable TV (and ways to poach it) and new telecommunications rental markets have spread throughout the urban area along with courier services, xerox and video libraries. The town can now give up at least 20,000 'doses' of cinema per day. The explosion of finance companies and chit funds, many not registered, many run with black money, the appearance of insurance, stocks and share dealing services, specialised commercial agencies for corporate industry, architectural, accountancy and real estate professions attest to the 
emergence of sizeable elite markets. Tuition centres, typing and computing institutes and students' hostels indicate new patterns of skill acquisition and freedom for young people (although the town is extremely underdeveloped with respect to education). Auto sales and rentals, tourist cars and vans businesses have responded to local piety, curiosity and incomes (for tourism is inextricably linked with pilgrimages and shrinehopping). Prominent expansions of hotels, bakeries and sweets stalls and booths indicate new patterns of commensality. Modernisation has not simplified the institutional fabric. Quite the reverse. All these developments have added to the institutional complexity of the town. But while in terms of numbers of enterprises the town appears a model of a growth centre, the prevalence and distribution of black finance capital suggests that there is a substantial element of accumulation which is non-productive. From field research we estimate that the output from trade and the income from finance equals or exceeds that from productive industry in Arni.

The vast mass of businesses are family firms with small labour forces. The average number of livelihoods (seven to eight per firm) has not changed much over the period 1973-93. The proportion of purely family firms (petty commodity producers and traders) has risen from 28 per cent to 35 per cent over the 20 -year period, while the proportion of family labour in the entire labour force has remained static at around a quarter. The composition of this work force has changed with the entry of female family members of all castes. The mills however have become increasingly 'satanic' over time, through the casualisation of their labour force. Casual labour has increased from 23 per cent of jobs to 57 per cent between 1973 and 1993.

Forward Caste control over business is stable in absolute terms and their apparent proportional decline masks the massive increase in concentration of their capital. Backward Castes (BCs) have gained ground as owners, while Most Backward Castes (MBCs) and Scheduled Castes (SCs) make up around 80 per cent of the casual labour force. ${ }^{1}$ Ten to 15 per cent of firms still only employ labour of their own caste. In the great majority of firms using wage labour, workers form an emulsion of caste.

In the 1990s, the town has swept by a new wave of accumulation from the lower agrarian castes that is primitive in two senses of the term. First, though capitalist production relations have been long entrenched, each individual capitalist has to develop his (sic) own starting point for accumulation. This primary capital may be obtained by inherited profits and assets but may also be got legitimately from loans and from savings from wage work. Second, however, another element in these initial resources, even when acquired in the modern economy, is got in 'primitive' ways through the exploitation of informalised and rightless labour, through crime, fraud and corruption [Harriss-White, 1996]. Not accustomed to the concept or practice of state-mediated accountability, never having been 
taxed as agricultural producers, their subsequent trajectories of accumulation are also fuelled by tax evasion.

\section{THE POLITICS OF ACCUMULATION IN ARNI}

Field material shows that of late Arni's economy has been organised into a large number of private and state institutions (66 of them in 1997), covering all aspects of social and economic life, and regulating it at the levels of the (male) individual, the household and the collective. Some are of long standing. Public service and public sector unions, together with some of the politically militant but numerically small service castes, were the first institutions to be created in the early part of the century. But over half have appeared since 1980 and 35 per cent in the 1990s. The latter are based on new principles of organisation: new political parties, town level, cross-caste organisations, trade associations for new goods and services, organisations for scheduled castes and a handful for women. Many associations have a cross-class nature and individuals (men) participate irrespective of their class position. This aspect of corporatist organisation is most apparent in the castecum-occupational associations but it holds for others, particularly welfare and charitable organisations. The interests of culture and religion also come to be organised increasingly through caste associations. Then such organisations come not only to reflect culture and religion but also political and business objectives. Indeed the latter come to dominate the organisations and the urban economy cannot operate without them.

There is a strong ideological element to these groups. Alongside a regulative economic agenda and claims from the state, practically every caste association aims to improve their own welfare and solidarity, reproducing within a caste an echo of the distributional rules that formerly operated between castes in this region. Groups representing more economically powerful interests also aim to improve (or to be seen to improve) the welfare of the town itself, albeit through small acts of redistributive charity which are also open to interpretation as legitimating accumulation. These attempts at self-regulation and economic governance are supported by a widespread ideology that conceals class interests under the veil of the wider interest of the 'community'. It is worth stressing that the strength of 'town-unity' extends across religions. Of some significance is the role of Muslim businessmen not only as Muslims but also as businessmen, as representatives of the town and as collective investors in (secular) educational infrastructure egregiously neglected by the state [Harriss-White, 2002a].

Caste is also a key pillar of the ideology in which the town presents itself a'unified body'. To date it is showing no sign of the erosion foreseen by Panini and others. Instead it is being selectively reworked to mean different things at different positions in the economic system of the town. Among 
Scheduled Castes and Most Backward Castes, caste remains a condition of hierarchy in which higher castes are repelled from low-caste occupations, in which access to higher-caste occupations is prevented. Caste is the more subtly present when it cannot even be used as an idiom in the organisations struggling for income and status. These have to be labelled by occupation: sanitary workers, fruit and vegetable sellers organisations. By contrast, among Backward Castes, caste is more a matter of difference, economically competitive and increasingly internally differentiated. Here we see the contradictions of practices signifying a rise in status on the one hand and pressure on the state to lower status for the purposes of positive discrimination on the other. At the top, caste ceases to have an apparent role to play in formal economic regulation, though it certainly does not cease to have a role in economic and social life. It continues to supply the grounds for marriage alliances, which in turn structure joint control over commercial assets, the reputation of firms and access to credit. So there is a distinct interplay between the economy and caste (and caste-based occupational) associations, which reveals the flexibility of caste, the reworking and distancing between caste and religion and the adding of economic regulative functions both to the institution of caste per se and particularly to its formal associations. For if castes are 'truncated and secularised' institutions which have lost their religious bearings, they are ineluctably vital as regulators of the economy. It seems that the sanskritising agenda of the caste associations has been sacrificed on the altar of the economy.

The interplay between caste and the economy may be differentiated but it is consistent with corporatism. Corporatism, let us recapitulate, limits class conflicts inter alia by involving both capital and labour in the 'selfgovernment' of the economy. It rests on two pillars, one institutional and one ideo logical. Toegther they impregnate production relations and link economy and society in a distinctively corporatist manner. In this we think caste plays a triple role. First, it provides an ideological backcloth for the corporatist 'project'. Second, it generates, and is consistent with the formalisation of, the institutional structure on the back of which corporatist organisations have evolved. In this urban society, caste still supplies the kind of hierarchical order that was entrusted to the state in the Italian case [Mancini et al., 1983]. Through the caste system, the link between ideology and institutions is particularly strong. The ideology itself, in distinguishing castes, is the source of the institutions-caste and closely related, finely defined occupational associations. Third, caste helps in the creation of the conditions for the overlap between economy and society that are necessary for the working of the corporatist project. The corporatist ideological and institutional framework imprints production relations, the main features of which can be distinguished through: (1) class 
relations; (2) gender; (3) the local territorial organisation of the urban economy and (4) relations between the urban economy and the state.

\section{Capital-Labour Relations}

The town is organised according to the needs of local 'big' capital. However, local 'big' capital does not act in concert, but is divided by commodity and by caste. It is not weakened by such a political configuration. Rather the latter may be seen as the hydra-headed alignments of a numerically small sector which maximise a set of tactical advantages. Witness for example the ubiquitous atttempts collectively to regulate and control via the state where necessary the markets in which these firms are enmeshed: those for raw materials, money, rates in derived markets and most particularly labour. The modalities of labour control include wage rates but also the means of increasing 'absolute surplus value' (the terms and conditions of work, the length of the working day and week, the extent and periodicity of holidays, the deliberate use of casual female and child labour). Through this control, capital is able to transform labour productivity extensively and without a rise in mass consumption. In so doing capital frequently flouts the laws regulating and protecting labour. At the same time accumulation is permeated with petty crime and with widespread fraud particularly with respect to every aspect of taxation.

Labour is weak and not organised. Independent trade unions are almost non-existent and party political support is opportunistic. Associations of low castes and unions of workers are no different from big commodity associations in this respect. There is practically no organised complaint or rebellion about working conditions, in spite of the fact that, as the major business asso ciations reported, the town is close to full employment. A modern proverb has it that 'Caste is the strongest trade union', but even among low-caste workers, caste is not organising 'labour' in opposition to 'capital'. In certain castes, occupations with a long history of casteidentification are vigorously defended for a mixture of purposes, such as social identity, insurance, trust and economic reputation, job security and credit, but extremely rarely for class identity. Caste has become an instrument to regulate workers' participation in the economy, rather than to legitimate caste/class opposition or to position people in a ranking of ritual status.

Capital and labour are out of balance as far as class consciousness is concerned. The capitalist class has a strong identity that is reinforced by convictions about the duties of the local elites in promoting urban welfare, while labour has a very weak perception of its class identity due to the absence of political representation and to the pervasive presence of caste. But there are other institutions than caste which structure accumulation 
and with which caste is more or less entwined: gender, locality and the state.

\section{Gender}

While just under half the workforce is female, while a handful of businesses are managed by women, practically no business is owned by women and corporate associational life is intensely male. Educated women, extremely few of whom are Scheduled Caste and even fewer Backward Caste, have economic niches in clerical jobs in local government, medicine, teaching, and a toehold in the professions. It is very rare to find a woman lawyer or member of the police force. Even in the late 1990s, those with other skills, such as computing, worked in organised-sector firms outside the locality, on the outer periphery of Arni's collective life. The economic role of women is largely confined to being the vehicles for transfers of assets at marriage and to buttressing the ideological legitimation of the business/caste elite through cross-caste and class philanthropy. Women are but tiny minorities in a few caste and trade associations and where they form an important minority their corporate affairs are managed by men, just as the interests of labour are frequently managed by capital. As labour, women are deliberately casualised and attempts to organise them are crushed. Urban civil society therefore tends towards the reinforcement of patriarchy in the market economy. By contrast, it is the local state which has provided opportunities for the relative empowerment of women, through education and through employment, though women are still conspicuous by their absence in the higher ranks of the administration.

\section{Locality}

There are two aspects of locality which shape the organisation of the economy. First, since the tidal wave of commercial capitalist expansion in the 1960s, the town has organised itself as a social unit across caste and to a lesser extent across class and gender. The purposes of this unity have evolved. At first socially redistributivist, they developed to include enabling and claiming activity and latterly to substitute for the state. In its new, composite role, 'town unity' is pitted against the state as much as providing a crutch for it.

The second aspect of the organisation of locality concerns its spatial and political dynamics. Those civil-social organisations which are not federated operate politically at the level of local municipal government, monitoring the local state and demanding public infrastructure. But the majority of civil social organisations are components of hierarchical federations with their apexes in state or national capitals. This has two further ambivalent 
consequences: local organisations have access to higher levels of skill and resources in their political and economic projects; but they may also be construed as passive conduits of information and instructions from headquarters and/or to be mobilised reactively in a competitive political arena sited elsewhere.

\section{State}

The economic role of civil-social organisations is part self-regulative but for the most part it is directed towards the state. The state in the town is empowered to organise, mediate, protect, regulate and redistribute economic resources. In doing so it redistributes economic power between the genders, shapes the fortunes of castes, creates and regulates classes and formalises locality. If it ever was a secular institution, it is definitely being desecularised in the current era. Its efficacy is being shaped by the private social status of its officials [Harriss-White, 2002b]. At the same time, it is also riddled with incompetence, arbitrary bureaucratic behaviour and oppressive practices. Private interest and private discretionary power generate corruption and the party-political capture of discretionary bureaucratic power feeds rivers of private tribute. Much more quantitatively important than corruption, however, is fraud, in which the benefits of non-compliance are shared between individual politicians and the local business elite. Clearly, this is a collaborative state. But one thing its collaboration does not involve is control over the civil-social institutions described here. The state does no more than permit and tolerate this form of corporatist regulation.

It is this state to which political appeal is made through caste and trade associations. Our field material suggests seven aspects to this set of claims: (i) price controls and subsidies to combat the unruliness of market exchange; (ii) regulation (particularly of urban space while other aspects of the state's regulation of markets are energetically contested); (iii) direct commercial intervention (trading in raw materials or finished products, regulation of access, terms and conditions of finance and loans); (iv) infrastructure (not only physical infrastructure but also financial and social); (v) reservations and employment; (vi) collusion over control of labour; (vii) taxation. The sites, scales and political outcomes of these seven fronts for civic contestation vary. But as long as the state is embroiled in these struggles-and from our evidence its role is intensifying rather than declining over the decade of liberalisation [McCartney and Harriss-White, 2000]-there will persist not only the well-chronicled tension between political inclusion and economic exclusion but also the less acknowledged tensions about the terms of political inclusion. Those terms require the state to have an active redistributive role in the economy, while the 
resources with which to carry out this role are threatened by domestic tax evasion and international loan conditionalities.

An increasingly restive political society with new, and newly assertive parties and organisations representing lower castes, many of which have democratic formal structures of authority, does not necessarily mean that civil society is democratising. Instead, as electoral democracy deepens, a politics other than party-electoral politics is also emerging. Electoral politics is suffused with caste competition and caste blocs. Party political alignment and caste compete as principles for votes. The town is at a stage in its political development when electoral politics takes the shape of 'capitalist business', requiring private investment, employing labour and yielding profit. Returns accrue not simply through the crude and timebound mechanism of votes but through more subtle and enduring returns to corrupt intermediation, fraud, non-compliance and contractual allocations that are all possible once in power.

\section{CONCLUSION}

So Arni's societal corporatist regime of accumulation accords with a Gramscian concept of civil society. In Arni's civil society can be found the political, cultural and ideological hegemony of a single social group-the capitalist class-over the entire society. This class exerts its hegemony with the important support of a strong ideology based on transformations to caste. Due to the reinforcement of caste, patriarchy and the rhetoric of the town unity, economic interests and ideological factors overlap in exactly the manner Gramsci thought to be the essence of civil society. In this sense, the institutional framework of civil society is the outcome of social contradictions and conflicts, that are resolved thanks to an ideological framework the main role of which is to gain consent for the hegemonic project of the local capitalist class. Through the caste system and through patriarchy, ideology comes to form a significant component in the local social structures of accumulation.

\section{NOTE}

1. See Basile and Harriss-White [2000: footnote 18] for a discussion of caste nomenclature.

\section{REFERENCES}

Basile, E. and B.Harriss-White, 2000, 'Corporative Capitalism: Civil Society and the Politics of Accumulation in Small Town India', QEHWPS 38, www.qeh.ox.ac.uk: (Queen Elizabeth House Working Paper Series). 
Béteille, A., 1996, 'Caste in Contemporary India', in Fuller [1996a].

Cawson, A., 1985, 'Varieties of Corporatism: The Importance of the Meso-level of Interest Intermediation', in A.Cawson (ed.), Organised Interests and the State, London: Sage.

Fuller, C., 1996a, Caste Today, Delhi: Oxford University Press.

Fuller, C., 1996b, 'Introduction: Caste Today', in Fuller [1996a].

Goodman, R., White, G. and H.J.Kwon, 1998, The East Asia Welfare Model: Welfare Orientalism and the State, London Routledge.

Gramsci, A., 1975, Quaderni del carcere, Torino: Einaudi.

Harriss, B., 1991, 'The Arni Studies: Changes in the Private Sector of a Market Town, 1971-83', in P.Hazell and C.Ramasamy (eds.), The Green Revolution Reconsidered: The Impact of High Yielding Varieties in South India, Baltimore, MD and London: Johns Hopkins, pp.181-212.

Harriss-White, B., 1996, 'Liberalisation and Corruption: Resolving the Paradox', in B.Harriss-White and G.White (eds.), Liberalisation and the New Corruption, IDS Bulletin, Vol.27, No.2, Brighton: Institute of Development Studies, pp.3140.

Harriss-White, B., 2002a, India Working: Essays on Economy and Society, Cambridge: Cambridge University Press.

Harriss-White, B., 2002b, 'India's Religious Pluralism and its Implications for the Economy', QEHWPS82, www.qeh.ox.ac.uk (Queen Elizabeth House Working Paper Series).

Jayaram, N., 1996, 'Caste and Hinduism: Changing Protean Relationship', in Srinivas [1996].

Karanth, G.K., 1996, 'Caste in Contemporary Rural India', in Srinivas [1996].

Keane, J., 1988, 'Introduction', in J.Keane (ed.), Civil Society and the State, London and New York: Verso.

Kotz, D.M., McDonough, T. and M.Reich, 1994, Social Structure of Accumulation: The Political Economy of Growth and Crisis, Cambridge: Cambridge University Press.

Luckham R. and G.White (eds.), 1996, Democratisation and the South: The Jagged Wave, Manchester: Manchester University Press.

McCartney, M. and B.Harriss-White, 2000, "The "Intermediate Regime" and "Intermediate Classes" Revisited: A Critical Political Economy of Indian Economic Development from 1980 to Hindutva', QEHWPS 34, www.qeh.ox.ac.uk (Queen Elizabeth House Working Paper Series).

Mancini O., Perrillo, F. and E.Zagari (eds.), 1982, La teoria economica del corporativismo, 2 vols., Napoli: ESI.

Mendelsohn, O., 1993 'The Transformation of Power in Rural India', Modern Asian Studies, Vol.27, No.2, pp.805-42.

O'Sullivan, N., 198), 'The Political Theory of Neo-Corporatism', in A.Cox and N.O'Sullivan (eds.), The Corporate State. Corporatism and the State: Tradition in Western Europe, Aldershot: Edward Elgar.

Panini, M.N., 1996, 'The Political Economy of Caste', in Srinivas (ed.) [1996].

Radhakrishnan, P., 1996, 'Mandal Commission Report: A Sociological Critique', in Srinivas (ed.) [1996].

Reiniche, M.L., 1996, 'The Urban Dynamics of Caste: A Case Study from Tamilnadu, in Fuller [1996a]. 
Robinson, M. and G.White (eds.), 1998, The Democratic Developmental State, Oxford: Oxford University Press.

Schmitter, P.C., 1974, 'Still the Century of Corporatism?', Review of Politics, Vol. 36, No.1.

Srinivas, M.N., 1989, The Cohesive Role of Sanskritisation and Other Essays, Delhi: Oxford University Press.

Srinivas, M.N. (ed.), 1996, Caste: Its Twentieth Century Avatar, Delhi: Viking.

Uphadya, C., 1997, 'Culture, Class and Entrepreneurship: A Case Study of Coastal Andhra Pradesh', in M.Rutten and C.Uphadya, Small Business Entrepreneurship in Asia and Europe, Delhi: Sage.

White, G., 1993, 'The Political Analysis of Markets', in G. White (ed.), The Politics of Markets, Institute of Development Studies, IDS Bulletin, Vol.24, No.3.

White, G., 1996, 'Chinese Trade Unions in the Transitions from Socialism: Towards Corporatism or Civil Society?', British Journal of Industrial Relations, Vol.34, No.3.

White, G., Howell, J. and Shang Xiaoyuan, 1996), In Search of Civil Society in China, Oxford: Clarendon Press. 